\title{
ЗАВИСИМОСТЬ КОНКУРЕНТОСПОСОБНОСТИ ПРОАУКЦИИ АГРАРНОГО СЕКТОРА РЕГИОНОВ СКФО ОТ ФОРМЫ ХОЗЯЙСТВОВАНИЯ
}

\begin{abstract}
Аннотауия. Анализ отечественных и зарубежных научных работ выявил, ито исследований, учитывающих зависимость конкурентоспособности сельскохозяйственной продукции от формы организачии аграрного производства, практически нет. Большинство исследований посвящены определению конкурентоспособности организации или уровня конкурентоспособности продукиии. Целью данного исследования является установление зависимости конкурентоспособности продукции от формы хозяйствования в аграрном секторе регионов СКСDО. Ме тоды: системный, комплексный, аналитический, рейтинговый, гипотетический и др. Реалнзауия результатов, полученных в ходе исследования, будет способствовать принятию решений, направленных на эффективное использование ресурсного потенииала аграрного сектора экономики. Область прнменения результатов: результаты исследования могут быть использованы соответствующими органами государственной власти регионов СКСОО, специалистами и руководителями предприятий АПК, научными работниками, а также в учебном проиессе. Выводы: проведенное исследование выявило, что на современном этапе развития в аграрном секторе регионов СКФОО нет прямой зависимости конкурентоспособности по отдельным видам продукиии от формы хозяйствования. Сельскохозяйственные организации более конкурентоспособны, чем малые формы хозяйствования в производстве животноводческой продукиии. Производство растениеводческой продукиии более конкурентоспособно в малых формах хозяйствования. Высокая доля малых форм хозяйствования в производстве продукиии говорит о необходимости создания стимулов и условий для повышения конкурентоспособности их продукиии.
\end{abstract}

Ключевые слова: сельскохозяйственные организации, малые формы хозяйствования, средние иены производителей, интегральный показатель конкурентоспособности.

YUNUSOVA PATIMAT SULEIMANOVA

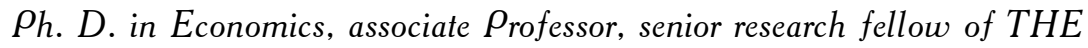
Institute of socio-economic research of the RUSSIAN ACADEMY of Sciences, e-mail: unus5252@mail.ru

\section{DEPENDENCE OF THE COMPETITIVENESS OF THE AGRICULTURAL SECTOR OF THE NORTH CAUCASUS FEDERAL DISTRICT ON THE FORM OF MANAGEMENT}

Abstract. The analysis of domestic and foreign scientific works has revealed that there are practically no studies that take into account the dependence of the competitiveness of agricultural products on the form of organization of agricultural production. Most studies are devoted to determining the competitiveness of an organization or the level of product competitiveness. The purpose of this study is to establish the dependence of product competitiveness on the form of management in the agricultural sector of the North Caucasus Federal district. Methods: system, complex, analytical, rating, hypothetical, etc. Implementation of the results obtained in the course of the study will contribute to decision-making aimed at effective use of the resource potential of the agricultural sector of the economy. Scope of the results: the results of the study can be used by the relevant state authorities of the regions of the North Caucasus Federal district, specialists and managers of agricultural enterprises, researchers, as well as in the educational process. Conclusions: the study revealed that at the present stage of development in the agricultural sector of the North Caucasus Federal district regions, there is no direct dependence of competitiveness for certain types of products on the form of management. Agricultural organizations are more competitive than small businesses in the production of livestock products. Crop production is more competitive in small businesses. The high share of small businesses in the production of products indicates the need to create incentives and conditions to increase the competitiveness of their products.

Keywords: agricultural organizations, small businesses, average producer prices, integrated indicator of competitiveness. 


\section{ЮНУСОВА П.С.}

ЗАВИСИМОСТЬ КОНКУРЕНТОСПОСОБНОСТИ ПРОДУКЦИИ АГРАРНОГО СЕКТОРА РЕГИОНОВ СКФО ОТ ФОРМЫ ХОЗЯЙСТВОВАНИЯ

Введение. На сегодняшний день в имеющейся научной литературе рассматриваются вопросы, связанные с оценкой конкурентоспособности региона, организации или уровня конкурентоспособности продукции. Исследований, учитывающих зависимость конкурентоспособности сельскохозяйственной продукции от формы организации аграрного производства, практически нет. Все это актуализирует тему настоящего исследования.

Гипотеза исследования заключается в следующем предположении: существует прямая зависимость между конкурентоспособностью сельскохозяйственной продукции и формой организации аграрного производства. Гипотеза проверена на примере разных форм хозяйствования в аграрном секторе регионов СКФО. Источником информации в данном исследовании послужили данные Росстата РФ.

Методика исследования. Для проверки данной гипотезы использована авторская методика оценки конкурентоспособности сельскохозяйственной продукции в сельскохозяйственных организациях (СХО) и малых формах хозяйствования (МФХ) [23]. В предыдущих исследованиях автором разработана также методика оценки уровня конкурентоспособности сельскохозяйственной продукции [24], на основе которой установлен сводный рейтинг регионов СКФО по конкурентоспособности сельскохозяйственной продукции [25].

Методика состоит из следующих этапов:

1. Определяются показатели оценки конкурентоспособности для каждого вида продукции. Выбор показателей осуществляется с учетом их наличия в статистической информации.

Для зерновых культур используются следующие показатели: доля организации в общем объеме производства, урожайность зерновых культур, средние цены производителей (СЦП); для производства мяса скота и птицы: доля организации в общем объеме производства, расход кормов в расчете на одну условную голову крупного рогатого скота (КРС), СЦП; для производства молока: доля организации в общем объеме производства, расход кормов на производство 1 ц молока, СЦП.

2. Показателю в форме хозяйствования, где он выше, присваивается один балл (без учета весомости показателя).

3. По совокупности баллов по всем показателям определяется форма хозяйствования в аграрном секторе региона, где конкурентоспособность определенной продукции выше.

4. Рассчитывается интегральный показатель конкурентоспособности по всем видам продукции в отдельных формах хозяйствования регионов СКФО.

Результаты. Анализ конкурентоспособности по производству зерновых культур свидетельствует о том, что интегральный показатель конкурентоспособности по их производству в регионах СКФО в целом был выше в МФХ (12 баллов). Существенную роль в производстве зерновых культур играют МФХ в Республике Дагестан и Кабардино-Балкарии, где интегральный показатель конкурентоспособности является максимальным (3 балла). В Чеченской Республике, напротив, интегральный показатель конкурентоспособности по производству зерновых культур максимальный в СХО (3 балла) (табл. 1).

Интегральный показатель конкурентоспособности по производству мяса скота и птицы на убой в живом весе выше в СХО (13 баллов). Максимальное количество баллов СХО набрали в Ставропольском крае (3 балла). Несмотря на это доля МФХ $(50,2 \%)$ в общем объеме производства незначительно, но выше, чем в СХО (49,8\%). Однако МФХ уступают СХО по двум другим показателям (табл. 2). Из табл. 3 следует, что ситуация с интегральным показателем конкурентоспособности по производству молока аналогичная - максимальное количество баллов набрали СХО (16 баллов), хотя основная доля молока производится в МФХ $(85,1 \%)$. Низкий уровень интегральных показателей конкурентоспособности по производству мяса скота и птицы на убой и молока в МФХ объясняется большим расходом кормов на 1 ц молока, высокими СЦП и низким надоем молока на 1 корову.

Интегральный показатель конкурентоспособности по всем видам продукции в отдельных категориях хозяйств регионов СКФО (табл. 4) свидетельствует о том, что в Республике Дагестан и Ингушетия СХО и МФХ имеют одинаковую конкурентоспособность (по 5 и 4 балла соответственно). В Карачаево-Черкесской Республике (5 и 4 балла), в Северной Осетии-Алания (7 и 3 балла), Чеченской Республике (7 и 3 балла) и Ставропольском крае (6 и 4 балла) конкурентоспособность СХО выше, чем МФХ. Только в Кабардино-Балкарской Республике конкурентоспособность СХО (4 балла) ниже, чем в МФХ (6 баллов). 
Производство зерновых культур в разрезе отдельных

Таблица 1 категорий хозяйств регионов СКФО в 2018 г.*

\begin{tabular}{|c|c|c|c|c|c|c|c|c|c|c|c|c|c|}
\hline \multirow{3}{*}{ Регионы } & \multicolumn{4}{|c|}{$\begin{array}{l}\text { Доля хозяйства в общем } \\
\text { объеме производства, \% }\end{array}$} & \multicolumn{4}{|c|}{ Урожайность, ц/га [22] } & \multicolumn{3}{|c|}{$\begin{array}{l}\text { Средние цены произво- } \\
\text { дителей, руб./тонн [20] }\end{array}$} & \multicolumn{2}{|c|}{$\begin{array}{l}\text { Количество } \\
\text { баллов }\end{array}$} \\
\hline & \multirow[b]{2}{*}{ CXO } & \multirow[b]{2}{*}{ МФХ } & \multicolumn{2}{|c|}{ В т. ч. } & \multirow[b]{2}{*}{ CXO } & \multirow[b]{2}{*}{ МФX } & \multicolumn{2}{|c|}{ В т. ч. } & \multirow{2}{*}{$\begin{array}{l}\text { Сред- } \\
\text { ние }\end{array}$} & \multirow[b]{2}{*}{ CXO } & \multirow[b]{2}{*}{ МФХ } & \multirow[b]{2}{*}{ CXO } & \multirow[b]{2}{*}{ МФX } \\
\hline & & & $\mathbf{X H}$ & $\begin{array}{c}\text { КФX } \\
{[19]}\end{array}$ & & & $\mathbf{X H}$ & КФХ & & & & & \\
\hline $\mathbf{P \Phi}$ & 70,2 & 29,8 & 0,8 & 29,0 & 27,2 & 21,4 & 20,8 & 22,0 & 8290,0 & 8495,8 & $\checkmark$ & 2 & 1 \\
\hline СКФО & 71,3 & 28,7 & 1,7 & 27,0 & 38,3 & 33,9 & 30,5 & 37,2 & 8799,5 & 9110,8 & 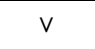 & 2 & 1 \\
\hline Дагестан & 41,6 & 58,4 & 42,6 & 15,8 & 24,4 & 24,7 & 30 & 19,3 & 8807,0 & 8995,1 & $\mathrm{v}$ & 0 & 3 \\
\hline Ингушетия & 64,9 & 35,1 & 6,6 & 28,5 & 21,8 & 26,0 & 28,1 & 23,9 & 7110,0 & 7223,8 & $\vee$ & 1 & 2 \\
\hline Кабардино-Балкария & 27,4 & 72,6 & 0,4 & 72,2 & 41,1 & 59,1 & 55,7 & 62,4 & 7881,3 & 7912,5 & v & 0 & 3 \\
\hline $\begin{array}{l}\text { Карачаево- } \\
\text { Черкессия }\end{array}$ & 44,8 & 55,2 & 8,8 & 46,4 & 51,7 & 39,0 & 34,5 & 43,4 & 8198,5 & 8832,2 & v & 1 & 2 \\
\hline $\begin{array}{l}\text { Северная Осетия- } \\
\text { Алания }\end{array}$ & 60,4 & 39,6 & 0,9 & 38,7 & 54,5 & 47,2 & 37,1 & 57,2 & 8661,5 & 8947,1 & v & 2 & 1 \\
\hline Чечня & 62,9 & 37,1 & 0,9 & 36,2 & 25 & 21,4 & 18,4 & 24,4 & 7744,3 & 7723,9 & $\wedge$ & 3 & 0 \\
\hline $\begin{array}{l}\text { Ставропольский } \\
\text { край }\end{array}$ & 79,8 & 20,2 & 0,1 & 20,1 & 38,2 & 30,1 & 28,7 & 31,5 & 8945,0 & 9228,1 & v & 2 & 1 \\
\hline Интегральный п & & & & & & & & & & C & & 9 & 12 \\
\hline
\end{tabular}

*Таблица составлена автором по данным Росстата.

Таблица 2

Производство скота и птицы на убой в живом весе в разрезе отдельных категорий хозяйств регионов СКФО в 2018 г.*

\begin{tabular}{|c|c|c|c|c|c|c|c|c|c|c|c|}
\hline \multirow{3}{*}{ Регионы } & \multicolumn{3}{|c|}{$\begin{array}{c}\text { Доля хозяйства в общем } \\
\text { объеме производства, \% } \\
\text { [13] }\end{array}$} & \multicolumn{3}{|c|}{$\begin{array}{c}\text { Расход кормов на } 1 \text { усл. } \\
\text { голову КРС, ц корм. ед. } \\
{[17]}\end{array}$} & \multicolumn{3}{|c|}{$\begin{array}{c}\text { Средние цены производите- } \\
\text { лей, руб./тонн [20] }\end{array}$} & \multicolumn{2}{|c|}{$\begin{array}{l}\text { Количество } \\
\text { баллов }\end{array}$} \\
\hline & \multirow[b]{2}{*}{ CXO } & \multicolumn{2}{|c|}{ МФХ } & \multirow[b]{2}{*}{ Средний } & \multirow[b]{2}{*}{ CXO } & \multirow[b]{2}{*}{ МФХ } & \multirow[b]{2}{*}{ Средние } & \multirow[b]{2}{*}{ CXO } & \multirow[b]{2}{*}{ МФХ } & \multirow[b]{2}{*}{ CXO } & \multirow[b]{2}{*}{ МФX } \\
\hline & & $\mathbf{X H}$ & $\begin{array}{c}\text { КФX } \\
{[19]}\end{array}$ & & & & & & & & \\
\hline РФ & 75,9 & 20,5 & 3,6 & 29,02 & 28,33 & $\wedge$ & 90028,3 & 86135,5 & $\wedge$ & 3 & $\mathbf{0}$ \\
\hline СКФО & 49,8 & 38,6 & 11,6 & 26,45 & 21,76 & $\wedge$ & 89773,3 & 67581,5 & $\wedge$ & 2 & 1 \\
\hline Дагестан & 20 & 61,6 & 18,4 & 22,14 & 23,15 & $\vee$ & 118440,8 & 95021,6 & $\wedge$ & 2 & 1 \\
\hline Ингушетия & 5,1 & 75,5 & 19,4 & 44,99 & 38,77 & $\wedge$ & 101172,0 & $\cdots$ & $\cdots$ & 1 & 1 \\
\hline Кабардино-Балкария & 30,3 & 41,9 & 27,8 & 38,85 & 35,11 & $\wedge$ & 139082,8 & 134156,2 & $\wedge$ & 2 & 1 \\
\hline Карачаево-Черкессия & 36,1 & 39,8 & 24,1 & 35,39 & 33,65 & $\wedge$ & 75050,0 & 65102,6 & $\wedge$ & 2 & 1 \\
\hline $\begin{array}{l}\text { Северная Осетия- } \\
\text { Алания }\end{array}$ & 16,7 & 76,8 & 6,6 & 31,24 & 24,71 & $\wedge$ & 131639,2 & 78930,4 & $\wedge$ & 2 & 1 \\
\hline Чечня & 3,7 & 84,1 & 12,3 & 33,74 & 30,35 & $\wedge$ & 82686,0 & 95940,2 & $\vee$ & 1 & 2 \\
\hline Ставропольский край & 76,1 & 19,9 & 4 & 22,74 & 18,67 & $\wedge$ & 70067,0 & 67356,8 & $\wedge$ & 3 & 0 \\
\hline $\begin{array}{l}\text { Интегральный показа } \\
\text { отдельных категорий }\end{array}$ & $\begin{array}{l}\text { конк } \\
\text { пйств }\end{array}$ & госп & $\begin{array}{l}\text { ости г } \\
\text { o }\end{array}$ & роизвод & скоте & птиц & а убой в & вом весе & разрезе & 13 & 7 \\
\hline
\end{tabular}

*Таблииа составлена автором по данным Росстата. 


\section{ЮНУСОВА П.С.}

ЗАВИСИМОСТЬ КОНКУРЕНТОСПОСОБНОСТИ ПРОДУКЦИИ АГРАРНОГО СЕКТОРА РЕГИОНОВ СКФО ОТ ФОРМЫ ХОЗЯЙСТВОВАНИЯ

Таблица 3

\section{Производство молока в разрезе отдельных категорий хозяйств регионов СКФО в 2018 г.*}

\begin{tabular}{|c|c|c|c|c|c|c|c|c|c|c|c|c|c|c|}
\hline \multirow{3}{*}{ Регионы } & \multicolumn{3}{|c|}{$\begin{array}{c}\text { Доля хозяйства в } \\
\text { общем объеме про- } \\
\text { изводства, \% [13] }\end{array}$} & \multicolumn{3}{|c|}{$\begin{array}{c}\text { Расход кормов на } 1 \text { ц } \\
\text { молока, ц корм. ед. } \\
{[17]}\end{array}$} & \multicolumn{3}{|c|}{$\begin{array}{c}\text { Средние цены производи- } \\
\text { телей, руб./тонн [20] }\end{array}$} & \multicolumn{3}{|c|}{$\begin{array}{c}\text { Надой молока на } 1 \\
\text { корову, кг [13] }\end{array}$} & \multicolumn{2}{|c|}{$\begin{array}{l}\text { Количество } \\
\text { баллов }\end{array}$} \\
\hline & \multirow[b]{2}{*}{ CXO } & \multicolumn{2}{|c|}{ МФХ } & \multirow[b]{2}{*}{$\begin{array}{l}\text { Сред- } \\
\text { ний }\end{array}$} & \multirow[b]{2}{*}{ CXO } & \multirow[b]{2}{*}{ МФХ } & \multirow[b]{2}{*}{$\begin{array}{l}\text { Сред- } \\
\text { ние }\end{array}$} & \multirow[b]{2}{*}{ CXO } & \multirow[b]{2}{*}{ МФХ } & \multirow[b]{2}{*}{ CXO } & \multicolumn{2}{|c|}{ МФХ } & \multirow[b]{2}{*}{ CXO } & \multirow[b]{2}{*}{ МФХ } \\
\hline & & $\mathbf{X H}$ & $\begin{array}{c}\text { КФX } \\
{[19]}\end{array}$ & & & & & & & & $\mathbf{X H}$ & КФX & & \\
\hline $\mathbf{P \Phi}$ & 53,1 & 38,7 & 8,2 & 0,98 & 1,03 & $v$ & 24435,3 & 22854,5 & $\wedge$ & 5945 & 3463 & 3689 & 3 & 1 \\
\hline СКФО & 14,9 & 69,7 & 15,4 & 1,13 & 1,07 & $\wedge$ & 31908,3 & 23610,9 & $\wedge$ & 3493 & 2541 & 2838 & 3 & 1 \\
\hline Дагестан & 16,0 & 65,9 & 17,7 & 1,07 & 1,01 & $\wedge$ & 33980,0 & 17356,4 & $\wedge$ & 2103 & 1675 & 2120 & 3 & 1 \\
\hline Ингушетия & 8,3 & 50,7 & 41,1 & 1,48 & 0,45 & $\wedge$ & $\ldots$ & $\ldots$ & $\ldots$ & 6696 & 3063 & 3070 & 2 & 1 \\
\hline $\begin{array}{l}\text { Кабардино- } \\
\text { Балкария }\end{array}$ & 12,1 & 70,1 & 17,9 & 1,19 & 1,13 & $\wedge$ & 17799,5 & 22928,9 & $\vee$ & 5070 & 3548 & 4061 & 2 & 2 \\
\hline $\begin{array}{l}\text { Карачаево- } \\
\text { Черкессия }\end{array}$ & 4,9 & 65,7 & 29,4 & 1,70 & 4,50 & 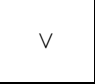 & 35752,8 & $\ldots$ & $\ldots$ & 3451 & 2815 & 3260 & 2 & 1 \\
\hline $\begin{array}{l}\text { Северная } \\
\text { Осетия- } \\
\text { Алания }\end{array}$ & 10,9 & 83,8 & 5,3 & 0,63 & 0,57 & $\wedge$ & 31577,8 & 24383,8 & $\wedge$ & 5271 & 4395 & 4716 & 3 & 1 \\
\hline Чечня & 7,9 & 87,5 & 4,6 & 1,10 & 0,60 & $\wedge$ & 40268,0 & 23470,3 & $\wedge$ & 6647 & 2545 & 2652 & 3 & 1 \\
\hline $\begin{array}{l}\text { Ставрополь- } \\
\text { ский край }\end{array}$ & 24,9 & 67,5 & 7,6 & 1,04 & 1,05 & $\vee$ & 23221,8 & 24567,2 & $\vee$ & 6268 & 4227 & 4328 & 1 & 3 \\
\hline $\begin{array}{l}\text { Интегральны } \\
\text { зяйств региоІ }\end{array}$ & ока & $\mathrm{Ib} \mathrm{r}$ & & & & por & дству & ка в ра & OT & IX & & & 16 & 10 \\
\hline
\end{tabular}

*Таблица составлена автором по данным Росстата.

\section{Расчетные параметры по выявлению конкурентных преимуществ отдельных форм хозяйствования в регионах СКФО*}

Таблица 4

\begin{tabular}{|c|c|c|c|c|c|c|c|c|}
\hline & \multicolumn{2}{|c|}{$\begin{array}{c}\text { Производство } \\
\text { зерновых культур }\end{array}$} & \multicolumn{2}{|c|}{$\begin{array}{c}\text { Производство } \\
\text { скота и птицы на } \\
\text { убой }\end{array}$} & \multicolumn{2}{|c|}{$\begin{array}{c}\text { Производство } \\
\text { молока }\end{array}$} & \multicolumn{2}{|c|}{$\begin{array}{c}\text { Интегральный показатель } \\
\text { конкурентоспособности } \\
\text { по всем видам продукции } \\
\text { в регионах СКФО }\end{array}$} \\
\hline & $\mathrm{CXO}$ & МФХ & $\mathrm{CXO}$ & МФX & $\mathrm{CXO}$ & МФX & $\mathrm{CXO}$ & МФХ \\
\hline РФ & 2 & 1 & 3 & $\mathbf{0}$ & 3 & 1 & 8 & 2 \\
\hline СКФО & 2 & 1 & 2 & 1 & 3 & 1 & 7 & 3 \\
\hline Дагестан & 0 & 3 & 2 & 1 & 3 & 1 & 5 & 5 \\
\hline Ингушетия & 1 & 2 & 1 & 1 & 2 & 1 & 4 & 4 \\
\hline Кабардино-Балкария & 0 & 3 & 2 & 1 & 2 & 2 & 4 & 6 \\
\hline Карачаево-Черкессия & 1 & 2 & 2 & 1 & 2 & 1 & 5 & 4 \\
\hline Северная Осетия-Алания & 2 & 1 & 2 & 1 & 3 & 1 & 7 & 3 \\
\hline Чечня & 3 & 0 & 1 & 2 & 3 & 1 & 7 & 3 \\
\hline Ставропольский край & 2 & 1 & 3 & 0 & 1 & 3 & 6 & 4 \\
\hline $\begin{array}{l}\text { Интегральный показатель } \\
\text { конкурентоспособности по } \\
\text { видам продукции }\end{array}$ & 9 & 12 & 13 & 7 & 16 & 10 & 38 & 29 \\
\hline
\end{tabular}

*Таблииа составлена автором по данным.

В целом по СКФО интегральный показатель конкурентоспособности по всем видам продукции в СХО (38 баллов) выше, чем в МФХ (29 баллов). В то же время в МФХ производится 
$50,2 \%$ мяса скота и птицы, 84,0\% молока.

Сегодня МФХ не является альтернативой СХО, а дополняют их. Они заполняют свою нишу в рыночной системе хозяйствования, как часть многоукладной аграрной экономики $[9, \mathrm{c}$. $68 ; 11,18]$. МФХ могут использоваться там, где высокий удельный вес затрат ручного труда; в производстве продукции с эксклюзивными потребительскими качествами; могут обслуживать локальные подразделения крупных предприятий и т. п. [6, с. 281; 10, 15, с. 500]. МФХ легче, чем крупные предприятия адаптируются к серьезным изменениям внешней среды $[5,27$, с. 57 ; 1$, c. $213 ; 3$, c. 852$]$.

МФХ выполняют не только производственные функции, но и участвуют в решении многих социальных проблем села, способствуют сохранению сельского образа жизни, развитию сельских территорий, обеспечивают гармоничное сочетание производства с окружающей природой. Они являются основным источником получения дохода для значительной части сельского населения, что особенно важно в условиях, когда идет постоянное сокращение работников аграрного сектора $[2,7,8,12,14$, с. 207].

В Указе Президента Российской Федерации от 21 декабря 2017 г. № 618 в качестве одного из основополагающих принципов государственной политики по развитию конкуренции определено обеспечение развития малого и среднего предпринимательства [21]. В рамках реализации данного Указа был разработан стандарт развития конкуренции в субъектах Российской Федерации. Одним из основных целей стандарта является «создание стимулов и содействие формированию условий для развития, поддержки и защиты субъектов малого и среднего предпринимательства, повышения уровня конкурентоспособности их продукции, а также содействие устранению административных барьеров» [16].

На необходимость дальнейшего развития МФХ президент России В.В. Путин указал и на встрече с представителями общественности по вопросам развития сельского хозяйства и сельских территорий, которая проходила в Адыгее. В частности, он «высказался за создание условий для развития мелких семейных фермерских хозяйств, пообещав рассмотреть вопрос о предоставлении таким предпринимателям земли без торгов» [4].

Вместе с тем мы согласны с мнением ученых-экономистов, которые считают, что будущее за крупными фермерскими хозяйствами и объединениями. Об этой тенденции К. Грей высказался так: «Крупно-товарное производство без всякого преувеличения обладает бесспорным преимуществом перед мелкотоварным производством. В общемировом масштабе крупные интегрированные, многоотраслевые хозяйства обеспечивают более половины мирового сельскохозяйственного производства, используя современные инновационные технологии» [26, 28 , с. 31]. Основными поставщиками товарной сельскохозяйственной продукции на мировые продовольственные рынки являются именно крупные фермерские хозяйства и объединения.

Выводы. Можно заключить, что гипотеза исследования не подтвердилась - сегодня нет прямой зависимости конкурентоспособности продукции аграрного сектора от формы хозяйствования. Показатели конкурентоспособности по производству зерновых выше МФХ, а по производству животноводческой продукции - в СХО. При соответствующей аграрной политике эта категория хозяйств может оказаться конкурентоспособнее, чем многие СХО. В МФХ меньше амортизационные отчисления, затраты на электроэнергию и ГСМ, а также транспортные расходы. Однако мировой опыт свидетельствует об обратном - крупные интегрированные, многоотраслевые хозяйства обеспечивают более половины мирового сельскохозяйственного производства за счет использования современных инновационных технологий. В регионах СКФО современные инновационные технологии в СХО и, тем более в МФХ, почти не применяются.

\section{Литература}

1. Авраменко, Е. С., Власов, С. В., Лукьянов, С. А., Темкина, И. М. Инвестиционная политика региона в условиях бюджетных ограничений и экономических санкций // Экономика региона. 2015. № 1. С. 213223.

2. Алиева, 3. А., Гашимова, Л. Г. Конкурентоспособность организачии как фактор эффективности инновационного менеджмента // Вопросы структуризации экономики. 2019. № 4. С. 139-141. DOI: 10.26159/APR.2019.79.4.032.

3. Алтухов, А. И., Дрокин, В. В., Журавлев, А. С. От стратегии обеспечения продовольственной независимости к стратегии повыпения конкурентоспособности агропродовольственного комплекса // Экономика региона. 2016. № 3. С. 852-864. 


\section{ЮНУСОВА П.С.}

ЗАВИСИМОСТЬ КОНКУРЕНТОСПОСОБНОСТИ ПРОДУКЦИИ АГРАРНОГО СЕКТОРА РЕГИОНОВ СКФО ОТ ФОРМЫ ХОЗЯЙСТВОВАНИЯ

4. Владимир Путин призвал создать условия для развития мелких семейных фермерских хозяйств [Электронный ресурс]. - URL : https://www.pnp.ru/economics/vladimir-putin-prizval-sozdat-usloviya-dlyarazvitiya-melkikh-semeynykh-fermerskikh-khozyaystv.html?utm_source=pulse_mail_ru\&utm_referrer=https\% 3A\%2F\%2Fpulse.mail.ru (дата обращения: 4.01.2020).

5. Гамидуллаев, Р. Б. Анализ потенциала и проблемы управления предприятиями АПК Республики Дагестан // Региональные проблемы преобразования экономики. 2018. № 1 (87). С. 18-24.

6. Довбий, И. П., Митрофанова, И. В., Глазкова, Н. Г. Тенденции, проблемы и перспективы сбалансированного и конкурентного развития аграрного предпринимательства в России // Экономика: вчера, сегодня, завтра. 2016. № 8. С. 281-301.

7. Дохолян, С. В., Петросяни, В. З., Курбанов, К. К. Регулирование развития аграрного сектора экономики проблемных регионов в условиях импортозамещения и поддержки местных товаропроизводителей (на примере Республики Дагестан) // Конкурентоспособность в глобальном мире : экономика, наука, технологии. 2017. № 11 (58). С. 1426-1429.

8. Идзиев, Г. И., Гаджиев, М. Д., Эльдаров, Э. М. Динамика промышленных и аграрных производств в Республике Дагестан // Региональная экономика и управление : электронный научный журнал. 2019. № 1 (57). C. 1 .

9. Мамаева, А. М., Гаджибекова, И. А. Повышение конкурентоспособности сельскохозяйственного производства (на примере СПК «Дагестан») // Совершенствование технологических прочессов в пищевой, химической и перерабатывающей промышленности : сб. научных трудов преподавателей, сотрудников, аспирантов и студентов технологического факультета ДГТУ. -Махачкала, 2018. С. 66-70.

10. Мукаилов, М. Д., Курбанов, К. К. Импортозамещение и активизация отраслевой структуры АПК проблемных территорий (на материалах СКФО) // Проблемы развития АПК региона. 2018. № 4 (36). С. 231-237.

11. Мумладзе, Р. Совершенствование эффективности деятельности мальх форм хозяйствования как важная часть реализаџии стратегии развития АПК России [Электронный ресурс]. - URL : https:// iknigi.net/avtor-roman-mumladze/127546-sovershenstvovanie-effektivnosti-deyatelnosti-malyh-form-

hozyaystvovaniya-kak-vazhnaya-chast-realizacii-strategii-razvitiya-apk-rossii-roman-mumladze/read/page-

9.html (дата обрашения: 1.12.2019).

12. Печеневский, В. Ф., Снегирев, О. И. Современные тенденции институционального развития аграрной структуры в центрально-черноземном макрорегионе // Региональные проблемы преобразования экономики. 2019. № 3 (101). C. 36-44. DOI: 10.26726/1812-7096-2019-3-36-44.

13. Приложение к сборнику (информаичя в разрезе субъектов Российской Федераиии) 2019 [Электронный ресурс]. - URL : https://gks.ru/folder/210/document/13226 (дата обращения: 4.01 .2020 г.).

14. Продовольственный рынок регионов России : новый вектор развития; под общ. ред. д.э.н. Ю.Г. Лавриковой, д.э.н. В.П. Негановой. - Екатеринбург : УрО РАН, 2018. DOI:10.17059/1_2018.

15. Пустынникова, Е. В., Ускова, Е. О. Формирование конкурентных преимуиществ корпоративных структур на основе интеграции кластерного типа // Экономика региона. 2017. T. 13. Вып. 2. С. 500-510. 16. Распоряжение от 17 апреля 2019 2. № 768-р. Стандарт развития конкуреничи в субъектах Российской Федерации [Электронный ресурс]. - URL : http://minec-rd.ru/normativnye_pravovye_akty/item/42 (дата обращения: 4.01.2020).

17. Расход кормов в хозяйствах всех категорий Российской Федераџии за 2018 [Электронный ресурс]. URL : https://gks.ru/folder/11110/document/13277 (дата обращения: 4.01.2020).

18. Солтанбекова, Д. К. Эффективность системы государственной поддержки мальх предприятий в Республике Дагестан // Вопросы структуризаџии экономики. 2018. № 2. С. 6-7. DOI: 10.24411/1813-3528 -2018-10017.

19. Социально-экономическое положение Северо-Кавказского федерального округа в 2018 г. - М., 2019.

20. Средние иень производителей сельскохозяйственной продукции, реализуемой сельскохозяйственными организациями [Электронный ресурс]. - URL : https://fedstat.ru/indicator/57693 (дата обращения: 24.12.2019).

21. Указ Президента РФ от 21 декабря 2017 г. № 618 «Об основных направлениях государственной политики по развитию конкуренции» [Электронный ресурс]. - URL : http://www.garant.ru/products/ipo/ prime/doc/71739482/ (дата обращения: 4.01.2020).

22. Урожайность зерновых и зернобобовых культур [Электронньй ресурс]. - URL : https://fedstat.ru/ indicator/31533 (дата обращения: 14.12.2019).

23. Методика оценки влияния форм хозяйствования на конкурентоспособность продукиии в аграрном секторе экономики // Региональные проблемы преобразования экономики. 2020. № 1. С. … DOI:

24. Юнусова, П. С., Абусуфянова, 3-Х. Т., Гасанов, И. М. Оиенка уровня конкурентоспособности сельскохозяйственной продукиии регионов СКФО // Региональные проблемы преобразования экономики. 2019. № 3. C. 58-68. DOI: 10.26726/1812-7096-2019-3-58-68.

25. Юнусова, П. С. Сводньий рейтинг регионов СКФО по конкурентоспособности сельскохозяйственной продукиии // Вопросы структуризаиии экономики. 2019. № 2. C. 46-54. DOI: 10.26159/APR.2019.77.2.009. 26. Baliyants, K. M., Dokholyan, S. V., Hidirova, S. Z., Zhamolatova, Z. N. The Resource Potential of the Agroindustrial Complex of the North-Caucasian Federal District as a Factor of Innovative Development of the Macro-region // International Journal of Economics and Business Administration. 2019. Vol. VII. Special Issue 1. P. 39-347.

27. Goddard, R. International Political Economy : State-Market Relations in a Changing Global Order. - Second edition. - Boulder: Lynne Rienner, 2003. P. 703.

28. Michael, S. Organizational Economics Research in the U.S. Agricultural Sector and the Contracting and Organizations Research Institute // American Journal of Agricultural Economics. 2004. No. 4. P. 1-15. 


\section{References:}

1. Avramenko, E. S., Vlasov, S. V., Luk'yanov, S. A., Temkina, I. M. Investicionnaya politika regiona v usloviyah byudzhetnyh ogranichenij i ekonomicheskih sankcij // Ekonomika regiona. 2015. № 1. S. 213-223.

2. Alieva, Z. A., Gashimova, L. G. Konkurentosposobnost' organizacii kak faktor effektivnosti innovacionnogo menedzhmenta // Voprosy strukturizacii ekonomiki. 2019. № 4. S. 139-141. DOI: 10.26159/APR.2019.79.4.032. 3. Altuhov, A. I., Drokin, V. V., ZHuravlev, A. S. Ot strategii obespecheniya prodovol'stvennoj nezavisimosti k strategii povysheniya konkurentosposobnosti agroprodovol'stvennogo kompleksa // Ekonomika regiona. 2016. № 3. S. 852-864. 4. Vladimir Putin prizval sozdat' usloviya dlya razvitiya melkih semejnyh fermerskih hozyajstv [Elektronnyj resurs]. - URL : https://www.pnp.ru/economics/vladimir-putin-prizval-sozdat-usloviya-dlya-razvitiya-melkikhsemeynykh-fermerskikh-khozyaystv.html?utm source $=$ pulse_mail_ru\&utm_referrer $=h t t p s \% 3 \mathrm{~A} \% 2 \mathrm{~F} \%$ 2Fpulse.mail.ru (data obrashcheniya: 4.01.20̄20)

5. Gamidullaev, R. B. Analiz potenciala i problemy upravleniya predpriyatiyami APK Respubliki Dagestan // Regional'nye problemy preobrazovaniya ekonomiki. 2018. № 1 (87). S. 18-24.

6. Dovbij, I. P., Mitrofanova, I. V., Glazkova, N. G. Tendencii, problemy i perspektivy sbalansirovannogo $i$ konkurentnogo razvitiya agrarnogo predprinimatel'stva v Rossii // Ekonomika: vchera, segodnya, zavtra. 2016. № 8. S. 281-301.

7. Doholyan, S. V., Petrosyanc, V. Z., Kurbanov, K. K. Regulirovanie razvitiya agrarnogo sektora ekonomiki problemnyh regionov v usloviyah importozameshcheniya i podderzhki mestnyh tovaroproizvoditelej (na primere Respubliki Dagestan) // Konkurentosposobnost'v global'nom mire : ekonomika, nauka, tekhnologii. 2017. № 11 (58). S. 1426-1429.

8. Idziev, G. I., Gadzhiev, M. D., El'darov, E. M. Dinamika promyshlennyh i agrarnyh proizvodstv v Respublike Dagestan // Regional'naya ekonomika i upravlenie : elektronnyj nauchnyj zhurnal. 2019. № 1 (57). S. 1 .

9. Mamaeva, A. M., Gadzhibekova, I. A. Povyshenie konkurentosposobnosti sel'skohozyajstvennogo proizvodstva (na primere SPK «Dagestan») // Sovershenstvovanie tekhnologicheskih processov v pishchevoj, himicheskoj $i$ pererabatyvayushchej promyshlennosti : sb. nauchnyh trudov prepodavatelej, sotrudnikov, aspirantov $i$ studentov tekhnologicheskogo fakul'teta DGTU. -Mahachkala, 2018. S. 66-70.

10. Mukailov, M. D., Kurbanov, K. K. Importozameshchenie i aktivizaciva otraslevoj struktury APK problemnyh territorij (na materialah SKFO) // Problemy razvitiya APK regiona. 2018. № 4 (36). S. 231-237.

11. Mumladze, R. Sovershenstvovanie effektivnosti deyatel'nosti malyh form hozyajstvovaniya kak vazhnaya chast' realizacii strategii razvitiya APK Rossii [Elektronnyj resurs]. - URL : https://iknigi.net/avtor-romanmumladze/127546-sovershenstvovanie-effektivnosti-deyatelnosti-malyh-form-hozyaystvovaniya-kak-vazhnaya-chastrealizacii-strategii-razvitiya-apk-rossii-roman-mumladze/read/page-9.html (data obrashcheniya: 1.12.2019).

12. Pechenevskij, V. F., Snegirev, O. I. Sovremennye tendencii institucional'nogo razvitiya agrarnoj struktury $v$ central'no-chernozemnom makroregione // Regional'nye problemy preobrazovaniya ekonomiki. 2019. № 3 (101). S. 36-44. DOI: 10.26726/1812-7096-2019-3-36-44.

13. Prilozhenie k sborniku (informaciya v razreze subëktov Rossijskoj Federacii) 2019 [Elektronnyj resurs]. URL : https://gks.ru/folder/210/document/13226 (data obrashcheniya: $4.01 .2020 \mathrm{~g}$.).

14. Prodovol'stvennyj rynok regionov Rossii : novyj vektor razvitiya; pod obshch. red. d.e.n. YU.G. Lavrikovoj, d.e.n. V.P. Neganovoj. - Ekaterinburg: UrO RAN, 2018. DOI:10.17059/1_2018.

15. Pustynnikova, E. V., Uskova, E. O. Formirovanie konkurentnyh preimushchestv korporativnyh struktur na osnove integracii klasternogo tipa // Ekonomika regiona. 2017. T. 13. Vyp. 2. S. 500-510.

16. Rasporyazhenie ot 17 aprelya 2019 g. № 768-r. Standart razvitiya konkurencii v subëktah Rossijskoj Federacii [Elektronnyj resurs]. - URL : http://minec-rd.ru/normativnye pravovye akty/item/42 (data obrashcheniya: 4.01.2020).

17. Raskhod kormov v hozyajstvah vsekh kategorij Rossijskoj Federacii za 2018 [Elektronnyj resurs]. - URL : https://gks.ru/folder/11110/document/13277 (data obrashcheniya: 4.01.2020).

18. Soltanbekova, D. K. Effektivnost' sistemy gosudarstvennoj podderzhki malyh predpriyatij v Respublike Dagestan // Voprosy strukturizacii ekonomiki. 2018. № 2. S. 6-7. DOI: 10.24411/1813-3528-2018-10017.

19. Social'no-ekonomicheskoe polozhenie Severo-Kavkazskogo federal'nogo okruga v 2018 g. - M., 2019.

20. Srednie ceny proizvoditelej sel'skohozyajstvennoj produkcii, realizuemoj sel'skohozyajstvennymi organizaciyami [Elektronnyj resurs]. - URL : https://fedstat.ru/indicator/57693 (data obrashcheniya: 24.12.2019).

21. Ukaz Prezidenta RF ot 21 dekabrya 2017 g. № 618 «Ob osnovnyh napravleniyah gosudarstvennoj politiki po razvitiyu konkurencii» [Elektronnyj resurs]. - URL : http://www.garant.ru/products/ipo/prime/doc/71739482/ (data obrashcheniya: 4.01.2020).

22. Urozhajnost' zernovyh $i$ zernobobovyh kul'tur [Elektronnyj resurs]. - URL : https://fedstat.ru/ indicator/31533 (data obrashcheniya: 14.12.2019).

23. Metodika ocenki vliyaniya form hozyajstvovaniya na konkurentosposobnost' produkcii v agrarnom sektore ekonomiki // Regional'nye problemy preobrazovaniya ekonomiki. 2020. № 1. S. .... DOI:

24. YUnusova, P. S., Abusufyanova, Z-H. T., Gasanov, I. M. Ocenka urovnya konkurentosposobnosti sel'skohozyajstvennoj produkcii regionov SKFO // Regional'nye problemy preobrazovaniya ekonomiki. 2019. № 3. S. 58-68. DOI: 10.26726/1812-7096-2019-3-58-68.

25. YUnusova, P. S. Svodnyj rejting regionov SKFO po konkurentosposobnosti sel'skohozyajstvennoj produkcii // Voprosy strukturizacii ekonomiki. 2019. № 2. S. 46-54. DOI: 10.26159/APR.2019.77.2.009.

26. Baliyants, K. M., Dokholyan, S. V., Hidirova, S. Z., Zhamolatova, Z. N. The Resource Potential of the Agroindustrial Complex of the North-Caucasian Federal District as a Factor of Innovative Development of the Macroregion // International Journal of Economics and Business Administration. 2019. Vol. VII. Special Issue 1. P. 39-347.

27. Goddard, R. International Political Economy : State-Market Relations in a Changing Global Order. - Second edition. - Boulder : Lynne Rienner, 2003. P. 703.

28. Michael, S. Organizational Economics Research in the U.S. Agricultural Sector and the Contracting and Organizations Research Institute // American Journal of Agricultural Economics. 2004. No. 4. P. 1-15. 